\title{
Variation in Blood Parameters of Rainbow Trout (Oncorhynchus mykiss) under the Influence of Seasons and Growth Systems
}

\author{
Vioara MIREŞAN, Daniel COCAN*, Radu CONSTANTINESCU, Camelia RĂDUCU, Octavian NEGREA \\ Faculty of Animal Science and Biotechnologies, University of Agricultural Sciences and Veterinary \\ Medicine, 3-5 Mănăştur Street, 400372 Cluj-Napoca, Romania \\ *Corresponding author, email: cocandaniel@yaho.com
}

Bulletin UASVM Animal Science and Biotechnologies 71(2) / 2014,

Print ISSN 1843-5262; Electronic ISSN 1843-536X

DOI:10.15835/buasvmcn-asb:10787

\begin{abstract}
It was examined the influence of seasons and farming systems on hematological profile of rainbow trout (Oncorhynchus mykiss). In the classical growth system, the mean values of hematological indices showed large variations, depending on the season. In the recirculating growth system, hematological indices were relatively constant, regardless of the season.
\end{abstract}

Keywords: rainbow trout, blood, season, growth system

Introduction. In physiologically terms, blood is considered to be a live fluid organ (Heilmeyer, 1968), which appears as a correlation element of all organs from the body. Any changes of biochemical and hematological composition of blood, is an expression of disease condition (Clauss et al., 2008; Declercq et al., 2013).

Aims and objectives. The purpose of our research was to determine the hematological changes in rainbow trout, under the influence of seasons and growth systems.

Materials and methods. This study was conducted in the period 2012-2013, in two different growth systems (a classical growth system, respectively a recirculating growth system). Were constituted two experimental groups, each of these with 600 rainbow trout. Blood samples were collected in every season, from 25 trout, from both systems.

Results and discussion. In the first group (reared in classical system), hematological parameters showed large seasonal variations under the influence of environmental factors. The difference recorded between the summer and winter seasons for hemoglobin ( $\mathrm{Hb}$ ) was $1.81 \mathrm{~g} /$ $\mathrm{dl}(\mathrm{p}<0.0001)$, for hematocrit (PCV) ( $\mathrm{d}=8.35 \mathrm{pg}$; $\mathrm{p}<0.0001)$ and the number of erythrocytes (RBC) $\left(\mathrm{d}=0.35 \times 106 / \mathrm{mm}^{3} ; \mathrm{p}<0.0001\right)$.

In terms of the number of leukocytes (WBC), the largest difference was recorded between the summer and autumn seasons $\left(\mathrm{d}=0.78 \times 104 / \mathrm{mm}^{3}\right.$; $\mathrm{p}<0.0001$ ). WBC/RBC report showed a highly significant difference between autumn and winter seasons $(\mathrm{d}=0.22 ; \mathrm{p}<0.001)$. Erythrocytic indices (MCH, MCHC, MCV) showed no significant seasonal differences. In our second experimental group exploited in a recirculating system, hematological parameters showed no statistically significant differences regardless of the season (Fig. 1,2).

Conclusion. Environmental factors have a major influence on blood parameters of rainbow trout. To exclude this inconvenience, with directly influence on growth rate, we recommend recirculating systems for raising trout. 

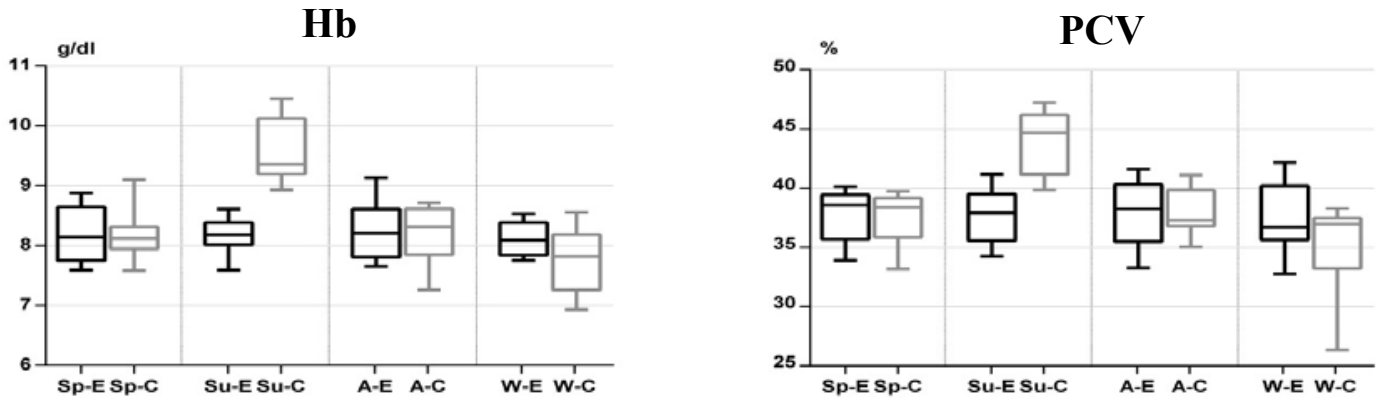

Fig. 1. Mean values and standard deviation of hemoglobin (Hb) and hematocrit (PCV) in rainbow trout (Oncorhynchus mykiss), depending by season and growth system (*black-classical growth system; gray-recirculating system)
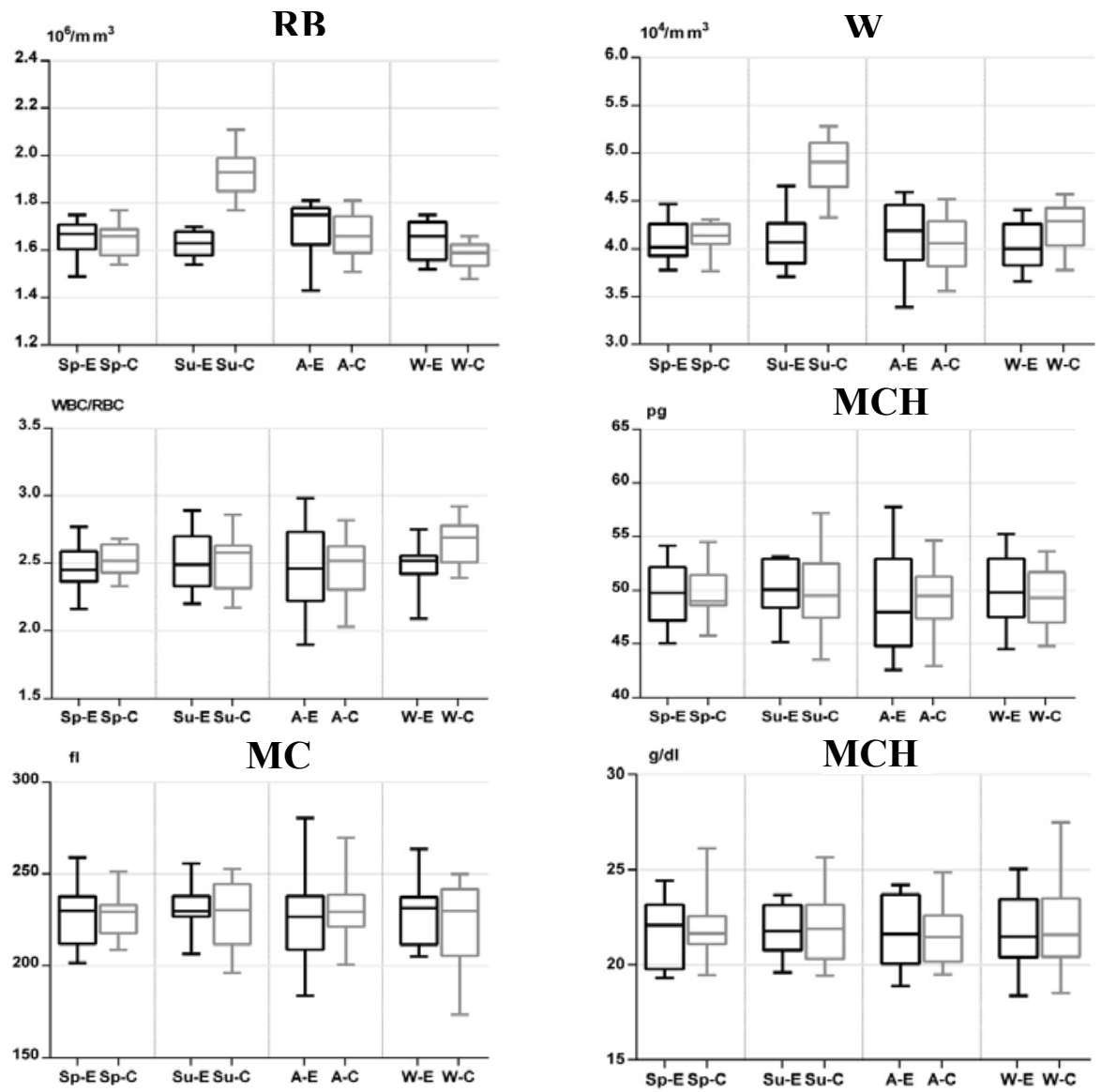

Fig. 2. Mean values and standard deviation of erythrocytes (RBC), leucocytes (WBC), leukocytes/erythrocytes report (WBC/RBC) and erythtocytic indices (MCH, MCV and MCHC) in rainbow trout (Oncorhynchus mykiss), depending by season and growth system (*black-classical growth system; gray-recirculating system)

\section{REFERENCES}

1. Heilmeyer L (1968). Fiziopatologie specială. Ed. Medicală Bucureşti.

2. Clauss TM, Dove ADM, Arnold JE (2008). Hematologic Disorders of Fish. Veterinary Clinics Exotic Animal Practice, 11: 445-462.
3. Declercq AM, Haesebrouck F, Van den Broeck W, Bossier P, Decostere A (2013). Columnaris disease in fish: a review with emphasis on bacterium-host interactions. Veterinary Research, 44(1): 27. 